\title{
Thematization of Power in D. H. Lawrence's Women in Love with reference to Nietzsche's - The Will to Power
}

\author{
Hishryar Muhammed Ameen, MA \\ University of Duhok, Iraq \\ Khorsheed Mohammed Rasheed Ahmed, MA
}

University of Zakho, Iraq

doi: 10.19044/esj.2016.v12n11p425 URL:http://dx.doi.org/10.19044/esj.2016.v12n11p425

\begin{abstract}
This paper gives a brief discussion on Nietzsche's - The Will to Power. It aims to thoroughly discuss how this theme has been reflected within the plot and characters of D. H. Lawrence novel Women in Love. This paper briefly talks about Nietzsche and his concept of The Will to Power, Nietzsche's influence over Lawrence, the relationships between characters in Women in Love and their significances, and The Will to Power and conflicts for dominations. Subsequently, it focuses on the Will to Power between male and female. Also, it considers social status as a source of power and authority. Finally, this study concludes on the type of Will to Power that is mainly reflected in Women in Love.
\end{abstract}

Keywords: Will to Power, Nietzsche's influence, Knowledge and Conflicts for Dominations, Power between Male and Female, and Social statue as Power and Authority

\section{Introduction}

As the theme of power has been dominant throughout the twentieth century, the name "Friedrich Nietzsche" has become one of the major names which have been recognized with the new dominant theme of power. Nevertheless, almost all the different fields of academic studies have been widely influenced by his approaches on power. This is because throughout the twentieth century, humankind has been preoccupied with the notion of power. Through the wake of philosophers such as Friedrich Nietzsche, this theme has spanned the conceptual "divide" between modernism and postmodernism. Also, this has increasingly dominated these diverse academic fields such as philosophy, economics, political science, and English literature (Hyde, 2010, p.1). Due to the reality of Nietzsche's wide 
influence over the academic thoughts, Lawrence was also influenced by his notions of power. As a result, he advocated a vitalism and individualism which often had parallels in the views of Nietzsche. In addition to this, he was also very obviously influenced by the new advent of the modern age. He was reacting against the industrialism and rationalism of the bourgeois world. Then, he saw the modern industrial world to be sexually repressive and to have a stunted human potential (Habib, 2011, p 194).

Hugh Steven (2007, p. 137) states that while Lawrence argues about the modern fiction and divides them into three types, he argues that two of the three types derive and propagate the self-consciousness. Thus, he considers it a big problem of the modern culture. Furthermore, he argues that at this point, Lawrence is influenced by his reading of Nietzsche. This is because self-consciousness is an awareness of self as separated from the natural world. It is a mental condition arising from the effects of the modern, rational, and scientific thoughts with its dualism and harsh delineation of subject and object.

\section{The Concept of The Will to Power}

Friedrich Nietzsche (1844-1900) was a German whose philosophy challenged the religious fundamentals and the traditional morals, especially those of the Western society. However, he has published many books and has enriched the world of thought with new ideas and philosophies. These ideas and philosophies have, however, influenced major people from different fields of thought and science. Furthermore, he had a great influence over literary scholars such as D. H. Lawrence. As Nietzsche saw that religion and governing system both use rules to force people toward implementing their plea without their own desire, he called for a new conception of humanity. Therefore, this conception is based on self-creation, passion, power, and subjugation of one's circumstances (Habib, 2011, p. 182). Nietzsche is best known for his conception of The Will to Power. This was despite the fact that he did not dedicate writing a book on this very frank title. However, his note book was published after his death under The Will to Power.

Consequently, the idea of The Will to Power is very obviously connected directly with life. In Beyond Good and Evil, Nietzsche says: "living things wants to discharge its strength - life itself is The Will to Power - self-preservation is only one of the indirect and most frequent consequences of this" (Nietzsche, 2002, p. 15). Furthermore, if we intend to better understand the concept of The Will to Power, we need to look at the sample judgment of some scholars. Heidegger (1987, p 15) in his book cited that Nietzsche states that, "Will to Power is the principle of new valuation; and vice versa, the principle of the new valuation to be grounded is Will to 
Power.” Another simpler interpretation of The Will to Power is presented by Belliotti (1998, p. 82). Hence, Belliotti stated that "the fundamental drive of all living things... [is] the impulse to dominate one's environment and extend one's influence.” Furthermore, he adds that this drive includes, "love, friendship, respect etc., which are all manifestations of the Will to Power" (Belliotti, 1998, p. 83). In addition to all these, Nietzsche viewed our pursuit for knowledge as not impartial, but as a manifestation of our "Will to Power" our fundamental motive of self-assertion, subjugation, and conquest, as well as our need for security (Habib, 2011, p. 183).

\section{A Short Summary of Women in Love}

Women in Love is one of the major books written by D. H. Lawrence in 1913. However, it was published in 1920. This story is about two sisters, Gudrun and Ursula, known as the Brangwen Sisters. Ursula Brangwen is the older and she is a teacher, while Gudrun Brangwen is an artist. The story starts with the two sisters discussing about marriage. One day, they decide to participate in a wedding party where they find their lovers. Usrula fell in love with Rupert Birkin, while Gudrun fell in love with Gerald Crich. Moreover, Birkin was haunted by an undesired relationship with Hermoine Roddice, a friend of the Crich's family. She is an aristocratic intellectual woman who was sometimes Birkin's lover. However, she wants to subjugate herself completely to Birkin. As a result, Ursula and Hermione became enemies. Hermione was ready to do everything to impose her power over Birkin, even if she meant smashing Birkin on his head. As such, the relationship between the two goes towards the end. Birkin goes back to Ursula. However, Birkin is sure about his feeling toward Ursula, but soon he finds himself to be in love with Gerlad. Also, Gerald had feelings toward Birkin too, but this confuses him due to his growing love for Gudrun.

As the story develops, the characters begin to profess their emotions towards each other. Ursula shows her readiness to marry Birkin, but there was a problem with the proposal plan. Therefore, this made Birkin angry and he goes to Gerald to find comfort. As time passes, they were engaged in an eroticized wrestling. Later, Birkin asked Ursula's hands in marriage from her father. Soon after they got married, Gerald suggests a winter picnic for both of them in Europe. Here, Gerald hopes that the picnic will be a way by which he develops the romance between him and his lover, Gudrun. Everything went on fine until Ursula tells Birkin that she loathes cold and they left. On the other hand, the relationship between Gerald and Gudrun was interrupted due to the interfering of a German artist named Herr Loerke, who was interested in Gudrun. Gerald will to dominate everything even Gudrun unveils here clearly when he hits Loerke badly and strangles Gudrun nearly to death. After this, he walks away to the middle of the cold snowy mountain 
and was freezed to death. Then, his corpse was brought back to the hostel. Birkin and Ursula came back again as soon as they hear the news of Gerald death.

\section{Section One}

Nietzsche's Influence over Lawrence

As a result of new industries and economic boom, life had faced dramatic changes in the new century. New issues and problems had been raised in the society. Lawrence was not neutral and speechless in the time of the booms of the new changes. This was also accompanied by new philosophical beliefs and thoughts. Thus, this was mainly that of Friedrich Nietzsche and its raising influences over the new era. Hence, D. $\mathrm{H}$. Lawrence's transformation to his Romanticism inheritance was his central life's work, and he did so as one who absorbed Nietzsche (Bell, 2001, p.178). While Nietzsche's philosophy started influencing various fields of thinking and intellectualism, Deleuze (2006, p. xv) argues that, [in] England, Nietzsche's influence was mainly over the novelists, poets, and dramatists.

The new changes of the age were different from the changes that had occurred in any other time in history. Therefore, it was not easy for people to assimilate and accept them easily and smoothly. It was even believed to be the age of crisis as was so called by many modernists who, "felt.....they were in a time of historical and spiritual crisis...” (Lawrence, 2007, p. xviii). In this age of crisis, D. H. Lawrence writings reflect Nietzsche's philosophy of power. His theme was dramatized in terms of a struggle between what he calls Will. Also, he manifests this will as the integration of the drive of ego towards power and domination. It has its inverse in the desire to be overpowered, to be dominated, and to yield everything to dissolution (Schorer, 1963, p. 57).

\section{The Relationships between Characters in Women in Love and their Significances}

Women in Love is formed from several different characters. Basically, two pairs of characters are the major focus in the story world, plus a number of other characters which do not undermine their role in conveying the central themes. There include a group of "free" characters, and a group of "bound" characters. The free characters are limited to four, while the four actively seek out their fate through the plot movement (Schorer, 1963, p. 53). Consequently, the four characters who were considered to be the free characters are Ursula and Gudrun who fell in love with Birkin and Gerald, respectively. That is, Ursula fell in love with Birkin, while Gudrun fell in love with Gerald. Lawrence has typical aims behind such creation of 
characters and relationships among them. Therefore, the relationship between each pair of lovers reflects different themes.

The relationship between Gerald and Gudrun represents death, while on the other side, the relationship between Birkin and Ursula represents life. "Gerald...was captivated by the cold sculptor Gudrun - their relationship represents "death". Birkin...established the polarized male and female relationship...with Ursula, and their relationship represents "life" (Zheng, 2010, 125). Furthermore, Jianjun Zheng argues that the theme of life and death of the characters reflects the type of personality, mentality, and thinking of characters. As life and death are two opposite things, the destiny, events which occurred, and conclusions of the two pairs of characters were different as well. Zheng also divides the characters into two different categories in terms of their will to powers and domination versus their sensuality and passion.

"Gudrun is a person to control, to possess, and to exercise her own Will to Power. She has the negative destructive mental self-consciousness in the depth of her soul... Gudrun belongs to the same group with Gerald, and their relationship represents death...Birkin symbolizes the natural, spontaneous life, the man alive and lived wholly as a man of integrity, the invincible life force that tries to overflow and stimulate him. While...Ursula is sensitive and protective, believes in true love...Together with Birkin, they are in Lawrence's sense "man alive and woman alive” (Zheng, 2010, p. 126).

Zheng further states that all other characters interact with the main characters and contributed to the theme of the novel.

\section{Knowledge as The Will to Power and Conflicts for Dominations}

Hermione could be considered as one of the main characters on the part of representing the typical symbol of The Will to Power in the novel. She is on a continual attempt of imposing her domination on her surroundings. Her behaviors and efforts of domination made her to be a symbol of The Will to Power. However, other characters, who tried to force their Will to Power on others, fell under her category. Furthermore, "Gudrun pits her will against Gerald. She is on her way of becoming his Hermione (Schorer, 1963, p. 56). In the vein, when Birkin visits Ursula in the classroom, Lawrence created a very strong argument between Birkin and Hermione. Hermione tries to demonstrate that the passion and sensation was a negative thing. She inquires whether or not Birkin thinks that children's minds could be harmed by bringing them to consciousness. Alternatively, Birkin considered the fact that it would be better to leave them without knowledge. Hence, this would simply make them animals. In her continuous 
speaking, Hermione considers knowledge as sever between human being and animals. Therefore, she stated that "it is better to leave them untouched, spontaneous. Is it not better for them to be animals, crude, violent, or anything, rather than being self-conscious or have no capacity to spontaneous?” (Lawrence, 2007, p. 40)?

She further expresses her position and argues that, "when we have knowledge, don't we lose everything but knowledge? If I know about flower, don't I lose flower and have only the knowledge? Are we not exchanging the substances for the shadow? Are we not forfeiting life for this dead quantity of knowledge? And what does it mean to me, after all? What does all this knowing mean to me? It means nothing!” (Lawrence, 2007, p. 41). As Hermione finishes her speech, Birkin answers her argument with an outburst of anger. However, as someone who knows her well to the extent that he knows what she hides behind her words, he replies: "Knowledge means everything to you! Even your animalism, you want it in your head. You don't want to be an animal, you want to observe your own animal functions to get a mental thrill out of them... Passion and the instincts-you want them hard enough, but through your head, in your consciousness. It all takes place in your head!” (Lawrence, 2007, p. 41). Consequently, this argument between Birkin and Hermione is actually an argument or to say a battle between passion and pure believing in the power of intellect and knowledge. As Birkin argues against Hermione, his argument and hard attack further continues. Thus, he accuses her that she only lusts for power and dominations which are her will. Birkin stated that she is not honest about her passion: "But your passion is a lie ... It isn't passion at all, it is your will. It's your bullying will. You want to clutch things and have them in your power...you only have your will, your conceit of consciousness, and your lust for power to know!” (Lawrence, 2007, p. 42).

Birkin goes on with his speech against Hermione and accuses her that she just wants everything in her way. He also stated that she is passionless and has no sense. Furthermore, he says that destroying her skull might turn her to a sensual woman. This offensive attack from Birkin against Hermione explains that she takes just one part of human configuration which is knowledge or intellect in reflecting her will. However, Birkin neglected the sense and creativity of the body: "for 'knowing' in the sense of incorporating and possessing intellectually is the mainspring of Hermione's internal life” (Black, 2001, p. 194).

Ursula, as Birkin, who falls within the same category of characters, opposes the modern will to knowledge and power. Thus, Ursula considers it as a destroyer of life. "We are tempted to agree with her [Ursula] that both the Romantic projects of natural supernaturalism and the modern will-toknowledge have even destroyed the private life: nothing was left, but the 
kingdom of death” (O’Hara, 1992, p. 155). Hermione’s rejection of sensual passion could stand even against the moral and sensual world of the novel. This is because Women in Love reflect a great part of the importance of sensuality and passion as an essential part of the human being's nature.

The above tenacious dialogue between Birkin and Hermione could embrace Nietzsche's statement on The Will to Power when he argues that, "The great rationality of all education in morality has always been that one tried to attain to the certainty of instincts. So, neither good intention nor good means had to enter into consciousness. As the soldier exercises, so should man learn to act. Thus, this unconsciousness belongs to any kind of perfection: even the mathematician employs his combinations unconsciously" (Kaufmann, 1968, p. 234). In reading the above passage of Nietzsche, it would be good to look at Kaufmann's remark on the mentioned passage from Nietzsche. Thus, this would bring more understanding and clarity:

"The mathematician who is able to handle complicated calculations "unconsciously" is not "unconscious" in the same manner; as he is, perhaps, an animal that acts on impulse. The "unconsciousness" that Nietzsche considers as a sign of power is what one might call an attained unconsciousness and a state of perfect mastery. Nietzsche considers both the man who acts on impulse and the man who deliberately counteracts his impulses to be inferior to the man who acts rationally on instinct" (Kafmann, 1974, p. 233).

\section{Section Two}

\section{The Will to Power between Male and Female}

In one of the chapters of Women in Love under the title "Mino", there is a clear emphasis on The Will to Power. When Ursula went up the hill to reach Birken's house, she felt as though she was dreaming. In fact, when she entered into a conversation with Birkin, she discovered more reality about life as she argues with Birkin about love and individuality. As they argue about life and love, suddenly their conversation turns to Mino, a male cat. Mino could symbolically represent a male in the society. However, Lawrence uses imagery to convey his ideas, and "[h]e is very good at drawing concrete symbols which can convey his theme from the ordinary objects of nature to characters" (Zheng, 2010 p. 126). When Mino boxes a female cat twice, Ursula gets upset and goes out to the garden to stop Mino from hitting the female cat. She, in turn, takes this opportunity to turn her attack on all males as she says, "Mino...I don't like you. You are a bully like all the males!” (Lawrence, 2007, p. 149). Furthermore, we found that Birkin opposes Ursula in that Mino is not a bully. Thus, he tries to justify what 
Mino did. Then, Ursula's answer moves more toward expressing The Will to Power. After calling Mino a bully, she cries out that Mino wants things its own way. Here, when she describes Mino, she uses the same phrases in which Birkin used before to describe Hermione's Will to Power and domination. The scene repeats itself here again. However, this time, Ursula accuses male of doing things in their own way. Thus, she portrays that male have a lust for power: "He wants his own way (I know what your fine words work down to) bossiness. I call it bossiness” (Lawrence, 2007, p.150).

Birkin expresses male superiority over female. In addition, he stated that males have a higher understanding and wisdom compared to females. Ursula opposes him and by saying that Birkin's ideology is "a real Willezurmacht- so base, so petty” (Lawrence, 2007, 150). Birkin agrees with her that The Will to Power is a petty thing. Nevertheless, he is still insisting on his idea based on the case of Mino. This is because it is a different will from the kind of The Will to Power which Ursula means. What he sees appropriate and alright with Mino is that, "it is the desire to bring this female cat into pure stable equilibrium, a transcendent, and an abiding rapport with the single male. Thus, without him, she is mere wanderer and a fluffy sporadic bit of chaos. It is a volonte' de pouvor...a will to ability..." (Lawrence, 2007, 150).

Thus, it can be said that from this argument, the two people were discussing two manifestations of power. Ursula is against the Will to Power, especially the type which reflects the lust of dominating other people. Birkin agrees with her in this viewpoint and approves her opposition against The Will to Power as domination. He insists that he is not concerned with domination, but rather concerned with the kind of The Will to Power which is in equilibrium between people that Ursula is likely to reject.

In a way, a comparison could be made between Hermione and Mino. This is observed during their expression of The Will to Power. Furthermore, Hermione as a female and Mino as a male are both representing The Will to Power. Such a comparison could possibly convey and support the argument in which The Will to Power exists. Thus, this occurs within human being regardless of their sex. Apart from human beings, it takes place in all living things which embraces Nietzsche's notion that, "All living things possess a Will to Power, although many do not have minds (Belliotti, 1998, p. 82)."

Mino uses its power and even takes advantage of its physical superiority over the female cat and hits it. On the other hand, Hermione also uses her physical power and attacks Birkin when she smashes his head. However, "Hermion is determined to dominate him with the force of her will” (Schorer, 1963, p. 54). Such comparison between Hermione and Mino could possibly make the readers to believe. Thus, this is based on the fact 
that Will to Power and domination strips human off all feelings and degrades them to the level of animals.

\section{Social Status as Power and Authority}

Gerald, the coal mine heir of his father, sees the work in the coal mine to be an exciting experience. The coal mine for Gerald is a real adventure because he can exercise his inner feeling of imposing power over people. Consequently, there were "so many wagons, bearing his initials that are running all over the country. He met with them when he entered London in a train. He saw them at Dover. So far, his power ramified" (Lawrence, 2007, p. 222). Therefore, this new position gives him a great sense of control and influence due to the power he receives from owning the coal mine. Thus, in another word, the coal mine is a source of power. With Gerald arriving into the city with his new posting to the coal mine industry, Lawrence has created an image which shows Gerald's sense of superiority arising from the new source of power. Therefore, "will is mechanical, and its symbol is therefore the mechanic" (Schorer, 1963, p. 57).

On the other hand, this scene could be looked at as the industrial power which turns majority of people (workers) into weak instrument in the hand of a more powerful person. Therefore, it made them inferior to him. Also, "they were all subordinate to him. Although they were ugly and untouched, they were his instrument. Thus, he was known as the God of the machine” (Lawrence, 2007, p. 223). Moreover, it could be argued that Lawrence reflects his real attitudes toward the impact of new industrial age over nature and society. He shows his opposition against the new form of power raised as a result of the development in the industrial fields. He was born and grew up in Eastwood, Nottinghamshire. Thus, he lived in an industrial area of coalfield where the waste produced by the coal industry had a negative impact on nature. Hugh Steven (2007, p. 142) in his essay, D. H. Lawrence: Organicism and the Modernist Novel, describes this effect of industry on nature. Therefore, he stated that "[t]hese stark contrasts are explored in most depth in Women in Love. All of which examines the impact of what Lawrence calls the mechanical on landscape and on our way of living. In addition, the modern has a demonic and fascinating power, which is an awful destructiveness.”

Subsequently, coal mine as to be a source of power for Gerald. It becomes a place where he can practice and reveal his will due to the reality of the will force. Thus, this drives human being toward its action. Basically, "the will of man was the determining factor. Man was the arch-god of the earth. His mind was obedient to serve his will. As such, man's will was regarded as absolute" (Lawrence 2007, p. 223). He further argues that it becomes more important for him. This is not based on the fact that it brings 
more money to him or because of his social position, but because it agrees with his will. Another picture of The Will to Power, which is reflected in Gerald, can be seen in his will of control even over his lover, Gudrun. Lawrence describes a scene when Gerald is with Gudrun, and he held her strongly. He describes this in a way that shows Gerald's inside will of domination and power over people and things. Therefore, the Will to Power and domination with Gerald began to have no boundary because it does not differentiate between strangers and non-strangers. As he receives his power from the mechanic to practice his will, it could be argued that this image reflects the danger of the new industries on the society.

"Under the bridge, they came to a standstill, and he lifted her upon his breast. His body vibrated taut and powerful as he closed upon her and crushed her, breathless and dazed and destroyed....Under this bridge, the collier pressed their lovers to their breast. And now, under the bridge, the master of them all pressed her to himself! And how much more powerful and terrible was his embrace, was how much more concentrated and supreme his love was..."(Lawrence, 2007, p. 330)

Gerald has power over everyone and everything. His will even moves to a higher level of domination to reach Gudrun. In this aspect, he could be reflecting Nietzsche's notion which stated that:

"The fundamental drive of all living things is the Will to Power, the impulse to dominate one's environment and extend one's influence. In humans, the Will to Power sometimes manifests itself as brute force, but more frequently requires creativity, boldness, and innovation. Nietzsche claims that the typical catalog of human desires was for love, friendship, respect, procreation, and biological nourishment” (Balliotti, 1998, p. 82)

Gudrun, who is Gerald's lover, is an artist who has a strong personality. Thus, she is not a common woman. She has a will of domination and power in herself. All by herself, she tries to do things in her own way. She is like Gerald in term of her Will to Power. Thus, they all belong to same categories of characters. However, "Gudrun belongs to the same group with Gerald” (Zheng, 2010, 126). Despite the power they have, they are both using it destructively. As for Gudrun, when it comes to her own interest, she gives up her lover to fulfill her will. Furthermore, she could have possibly killed Gerald by her will. As stated, "Gudrun pits her will against Gerald. She is on the way of becoming a Hermione. Moreover, since she is the deathseeking, not the life-seeking antagonist..., she kills him” (Schorer, 1963, p. 56). In this term, Lawrence's presentation of Gerald and Gudrun might embrace Nietzsche's thought. Thus, Nietzsche stated that, "Every 
animal...strives instinctively after an optimum favorable condition. Under this condition, he can play with his own whole strength, and achieves his maximum consciousness of power” (Nietzsche, 2003, p. 75).

\section{Conclusion}

Based on our analysis, we can arrive at the conclusion that Lawrence finds philosophy as a suitable window. Through this window, he can show his thoughts and beliefs about the changes of the modern age. This is based on the fact that the modern age is clearly influenced by Nietzsche's philosophy. Lawrence reflects the era of the modern world through his writing in a very proficient and skilled manner. Thus, he is even praised highly by other contemporary writers for his creativity and great responses to the modern era. For example, Ezra Pound praises him highly for his thoughts and ideas about modern age, "Yet even when Pound afterwards referred to Lawrence as a 'detestable person', he continued to acknowledge that Lawrence had discovered, before he had, the 'proper treatment of modern subject'. Hence, this was probably the highest compliment Pound would have made to anyone" (Bell, 2001, p. 179). As it is stated in the above lines that Lawrence is well aware of his age and all the new changes, Michel Bell (2001, p.178) says that, “... Lawrence, who when he first arrived in London astonished Ford Madox Hueffer with his knowledge of the nineteenthcentury literature. He understood the philosophical and psychological power, as well as the problems, of the Romantic tradition from within". Due to these realities, when it comes to reading Lawrence's work, there should also be a special focus on his philosophical messages.

As Lawrence argues the theme of The Will to Power and embodies them in his characters, it could be argued that he could be against Will to Power in terms of dominations. Based on the discussions outcome that shows that Gudrun is becoming Hermione, she has The Will to Power as domination. Also, she and Gerald share the same character traits. Subsequently, it can be argued that all the three characters that have will of domination, are falling under the category of the characters that represent death in the novel. As it was concluded in Women in Love, Lawrence expresses his rejection of The Will to Power as domination. Thus, he sees it as a destructive will which ends up the society in a black destiny and death. On the other hand, Birkin who reflects Lawrence himself in the story, falls within the same characters category with Ursula who represents the sensual side of the story world. However, "Ursula is sensitive and protective, and believes in true love" (Zheng 2010, p. 126). They reject the will as domination. As a result of this, it could be said that Lawrence is against will as domination. Thus, he believes more in the sensual side of human being. Furthermore, "Birkin, in a real sense, is a self-portrait of Lawrence, who 
fights against the cramping pressures of mechanized industrialism and the domination of any kind of dead formulas. He was presented as a symbolic figure of human warmth, standing for the spontaneous Life Force.” (Zheng, 2010, p. 127). Therefore, he believes that the new developments of the modern age will bring more destruction and death to the society rather than improvement. This is based on the fact that it leads to a negligence of the sensual and passionate sides of man, and it just depends on intellect.

\section{References:}

Bell (2001), "Lawrence and Modernism" in Fernihough, A. (ed.) The Cambridge Companion to D. H. Lawrence, Cambridge University Press, UK, Pp. 179.196

Belliotti (1998), "Stalking Nietzsche" Greenwood Press Westport, Connecticut: London

Black (2001), “Lawrence’s England, The Major Fiction” 1913-20”, Palgrave Macmillan, United Kingdom

Deleuze (2006), "Nietzsche and philosophy" Colombia University Press: USA

D. H. Lawrence (2007), “Women in love” Penguin classics: England Habib (2011), "Literary Criticism from Plato to the Present, an introduction" Wiley-Blackwell

Heidegger (1987), "Nietzsche: Vols. 3 and 4 (Vol. 3: The Will to Power as Knowledge and as Metaphysics"; Vol. 4: Nihilism). San Francisco: Harper and Rowe, Publishers Inc.

Hyde (2010), "Concepts of power in Kierkegaard and Nietzsche (New Critical Thinking in religion, Theology and Biblical Studies"Ashgate publishing limited: England,

Kaufmann (1974), "Nietzsche, Philosopher, psychologist, Antichrist" Princeton University Press: United Kingdom

Kaufmann (ed.) (1963), “Fredrick Nietzsche: Will to Power” New York: A Vintage Giant

Nietzsche (2003), “The Genealogy of Morals" Mineola, N.Y.: Dover Publications

O'Hara (1992), “The Power of Nothing in Women in Love” in Widdowson, P. (ed.), D. H. Lawrence: Harlow, Longman, UK

Schorer (1963), “Women in Love and Death" in Spilka, M. (ed.), D. H. Lawrence: A Collection of Critical essays: Englewood Cliffs, N.J.: PrenticeHall, Pp. 50.60

Steven (2007), “D. H. Lawrence: Organicism and the Modernist Novel” in Shiach, M. (ed.) The Cambridge Companion to Modernist Novel: Cambridge University Press, UK, Pp. 137.150 
Zheng (2010), "The Reinvention of Love and Death in Women in Love ", Asia Social Science, Vol. 6, No. 3, Pp. 125-127 